\title{
EVALUATION OF A LOCALLY MADE WHEAT GERM OIL EXTRACTING MACHINE
}

\author{
Mubarak, M.*; M. El-Nono *; T. R. Owies **; A.M. Abdel-Gawad **
}

\begin{abstract}
An expelling machine for extracting oil from wheat germ was designed and fabricated to be suitable for young investors. The procedures include the design stages, construction and testing. The main machine components are: Hopper (feeding inlet); expellant unit and an electric motor. The power is transmitted by means of a set of pulleys; sprockets; $V$-belt; chain and speed reducer (gear box). The expelling unit consists of two screw expellant shafts with two expellant barrels.

The expeller evaluated at five screw speeds (25, 35, 45, 55, and $65 \mathrm{rpm}$ ) and four levels of press head clearance $(0.5,1,1.5$, and $2 \mathrm{~mm})$ to determine the best Machine capacity $\left(\mathrm{kgh}^{-1}\right)$; Specific energy consumption ( $\mathrm{kWhkg}^{-1}$ feed); Oil recovery (\%); and Oil residual (\%) in wheat germ cake. The results showed that, the maximum barrel temperature was $65.5^{\circ} \mathrm{C}$ which assured production of good quality wheat germ oil, deoiled cake. The better oil extraction efficiency was at the speed of $25 \mathrm{rpm}$, when press head clearance was $0.5 \mathrm{~mm}$. The specific energy requirement was $0.042 \mathrm{kWhkg}^{-1}$ feed for the optimized pressing conditions.
\end{abstract}

\section{INTRODUCTION}

he wheat is one of the leading grain crops that produced,
consumed, and traded worldwide. In Egypt, about 17 million
metric tons of wheat was consumed in 2009 (FAO, 2010). Statistical data on wheat germ production is not readily available. However it can be estimated that about 340 thousand tons of wheat germ could be obtained from wheat milling operations based on the fact that germ constitutes about $2 \%$ of the whole wheat grain. Although wheat varieties differ in oil content, in general, the whole kernel contains about $2-4 \%$ lipids. Lipid content of endosperm is usually less than $2 \%$. Wheat germ contains about $10-14 \%(\mathrm{w} / \mathrm{w})$ oil (Dunford, 2005).

\footnotetext{
* Agric. Eng. Dep., Fac. of Agric., Ain Shams Univ., Cairo, Egypt. ** Agric., Eng. Res. Inst. (AEnRI), Dokki- Giza, Egypt
} 
Wheat germ oil (WGO) has the highest tocopherol content of all vegetable oils, up to about $2500 \mathrm{mg} / \mathrm{kg}$ (Shuler, 1990). It is highly valued due to its high content of unsaturated fatty acids: it has about 80\%, mostly linoleic (18:2) and linolenic (18:3) (Wang and Johnson, 2001). These two fatty acids are of great importance in human metabolism and can not be synthesized by the organism. They are precursors of a group of hormones called prostaglandins, which play an important role in muscle contractions and in the proper healing of inflammatory processes (Coultate, 1989). Furthermore, linoleic acid helps to eliminate cholesterol and is a precursor of cell membrane phospholipids.

Barnes (1982) mentioned that, WGO can be extracted by mechanical expelling, organic solvent extraction, and supercritical fluid extraction. Mechanical expression and organic solvent extraction are both being used for commercial purposes. To our knowledge, supercritical fluid technology has not been commercialized for WGO processing. Solvent extraction is by far the most widely used method to extract oil (Woerfel 1995). A mixture of hexane isomers containing about $60 \% \mathrm{n}$-hexane is the choice of solvent for commercial vegetable oil extraction. The residual oil content of solvent defatted wheat germ can be as low as $1 \%$ (w/w). Conventional methods have a tendency to generate crude extracts consisting of deteriorated constituents or to prematurely remove volatile components. Pressing recovers only $50 \%(\mathrm{w} / \mathrm{w})$ of the WGO. Mechanical pressing of oil is considered only when very high purity wheat germ with very low bran contamination is available (Barnes 1982).

Continuous screw presses are employed in technologically advanced areas where a sufficient raw material supply justifies a continuous operation. Screw presses exert much greater pressures (137 to $300 \mathrm{MPa}$ ) than hydraulic batch presses resulting in a greater recovery of oil (Peterson et al. 1983; and Bockisch 1998). In addition, screw presses have large processing capacities capable of handling 0.04 to $180 \mathrm{t} / \mathrm{h}$ of raw material (Carr 1997). Screw pressing has also been recognized as a suitable process for commercial production of organic edible oils from new oilseed crops (Singh et al. 2002) 
Singh and Bargale (2000) designed a screw press with two tapered screws which are mounted adjacently and concentrically as shown in Fig.(1). The seeds are compressed in two stages instead of one compression that is prior to exit. In this design, instead of a single stage compression as in the conventional screw presses, a compression ratio of 5:1 in the primary section and 3:1 in the secondary section is used. As a result, the design configuration avoids the possible damages of choking and jamming occurrences, which causes wear and tear of the machine components and result energy losses. Also, pressure required to recover the oil with $80 \%$ efficiency is decreased to the levels at which choking and jamming can not occur.

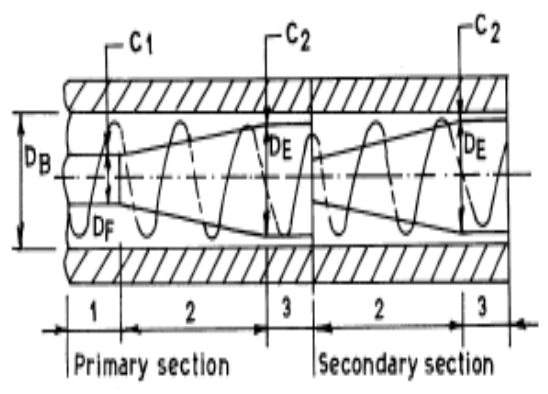

DB Barrel section

DF Root dia of screw at teed section

DE Root dia of screw at start of plug section

C) Clearance between the barrel and screw root at feed end

$C_{2}$ Clearance between the barrel and screw rool at slart of plug section

Fig.1. Principle of single-feed double stage compression used in the developed screw press.

Megahed (2011) studied the influence of periodical storage (at room temperature, $25-30^{\circ} \mathrm{C}$ ), on the stability of wheat germ oil including primary and secondary oxidation, total oxidation as well as conjugation. Color intensity at $430 \mathrm{~nm}$ of the oil samples was also evaluated to show changes of color during periodical storage. He generally found that peroxide value, $\mathrm{p}$-anisidine, total oxidation, conjugated diene and conjugated triene gradually proportionally increase at storage periods of $1,2,3,4,5,6$ and 7 days. Also he studied the lipase inhibition at $70^{\circ} \mathrm{C}$ during periods of 15,30 and $60 \mathrm{~min}$. He found that the fatty acid liberated at different periods decreased from $14.88(\mathrm{mg} / \mathrm{g}$ ) (control) to acid value of $12.02(\mathrm{mg} / \mathrm{g})$ after $60 \mathrm{~min}$. It seems that the acid value after $30 \mathrm{~min}$. at 
$70^{\circ} \mathrm{C}$ is suitable value to suppress the activity of enzyme and keeping the majority of oil triglycerides in the intact condition.

The objectives of this work were:

(i) To design and fabricate a small expeller for wheat germ oil expression.

(ii) To test the expeller in order to determine its optimum operating conditions.

\section{MATERIAL AND METHODS}

The experiments were carried out at Agricultural Engineering Research Institute (AEnRI) laboratory, Dokki-Giza in 2010. The experimental work involved two stages as follows:

- Manufacturing expeller (double stage compression screw press) for oil extraction. It should be:

- Simple in design, easy to fabricate, and

-Usable by anybody, even without any previous technical training.

- Testing the expeller for determining the best productivity and power consumption at five screw speeds $(25,35,45,55$, and $65 \mathrm{rpm})(0.08$, $0.11,0.14,0.17$, and $\left.0.2 \mathrm{~ms}^{-1}\right)$, and at four levels of press head clearance $(0.5,1,1.5$, and $2 \mathrm{~mm})$.

In order to fulfill the aim of the research through the consecutive stages of the work plan, the following materials; tools and methods were used:

\subsection{Expelling machine description:}

The manufactured expelling machine (double stage compression screw press) is illustrated schematically in Fig. (2) and photographed in Fig. (3). A complete description will be given in the next sections.

\subsubsection{Main frame:}

The main frame of the expeller was made of hollow square pipe steel (40×40×4 mm) with length $1100 \mathrm{~mm}$, width $650 \mathrm{~mm}$ and height $1150 \mathrm{~mm}$ in which all the parts of the expeller were fixed on it. 


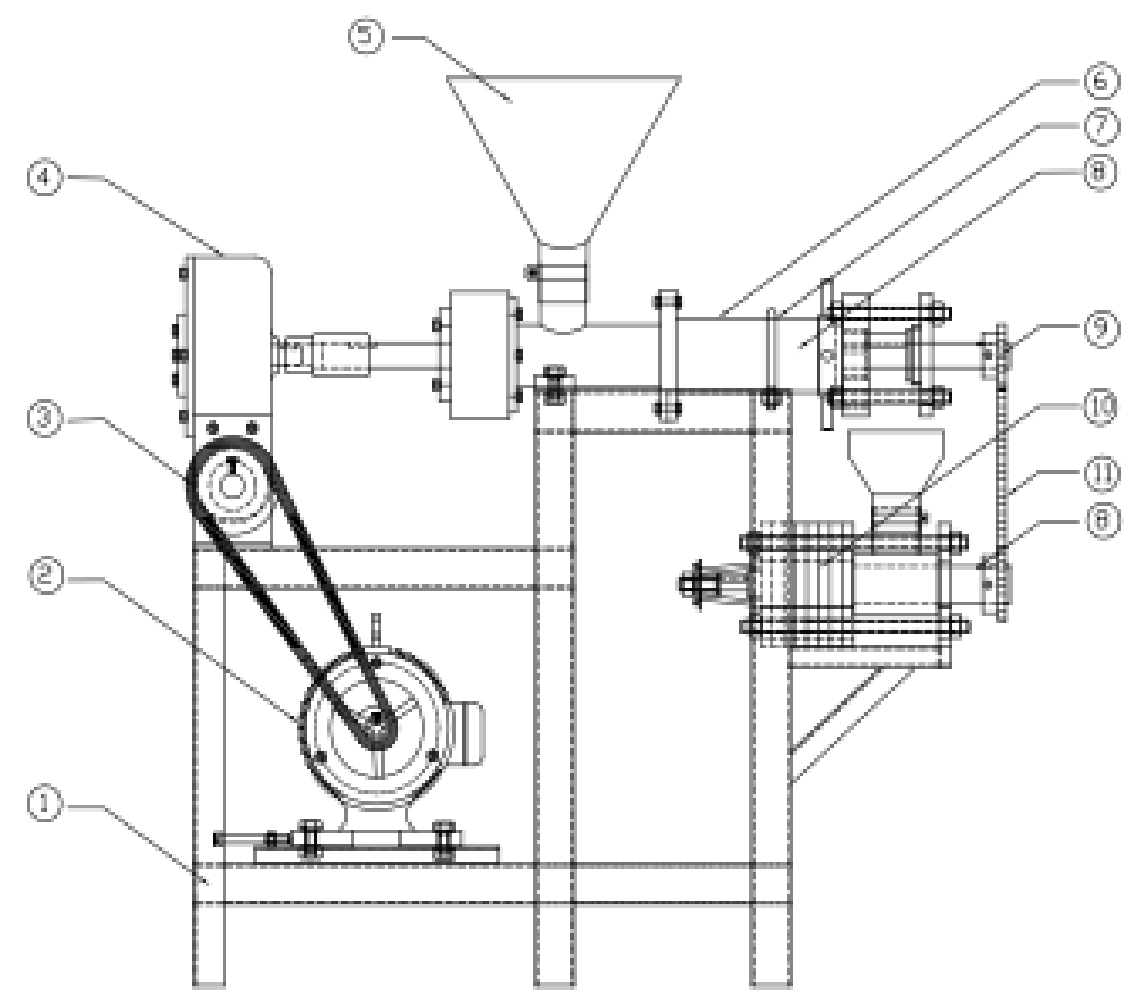

Fig.2. Schematic diagram of an expalling machine

1-Main frame. 2- Electric motor. 3- V-belt. 4- Gear box. 5- Hopper. 6- Bars barrel

7- Flange. 8- Screw press. 9- Sprocket. 10- Rings barrel. 11-Chain .

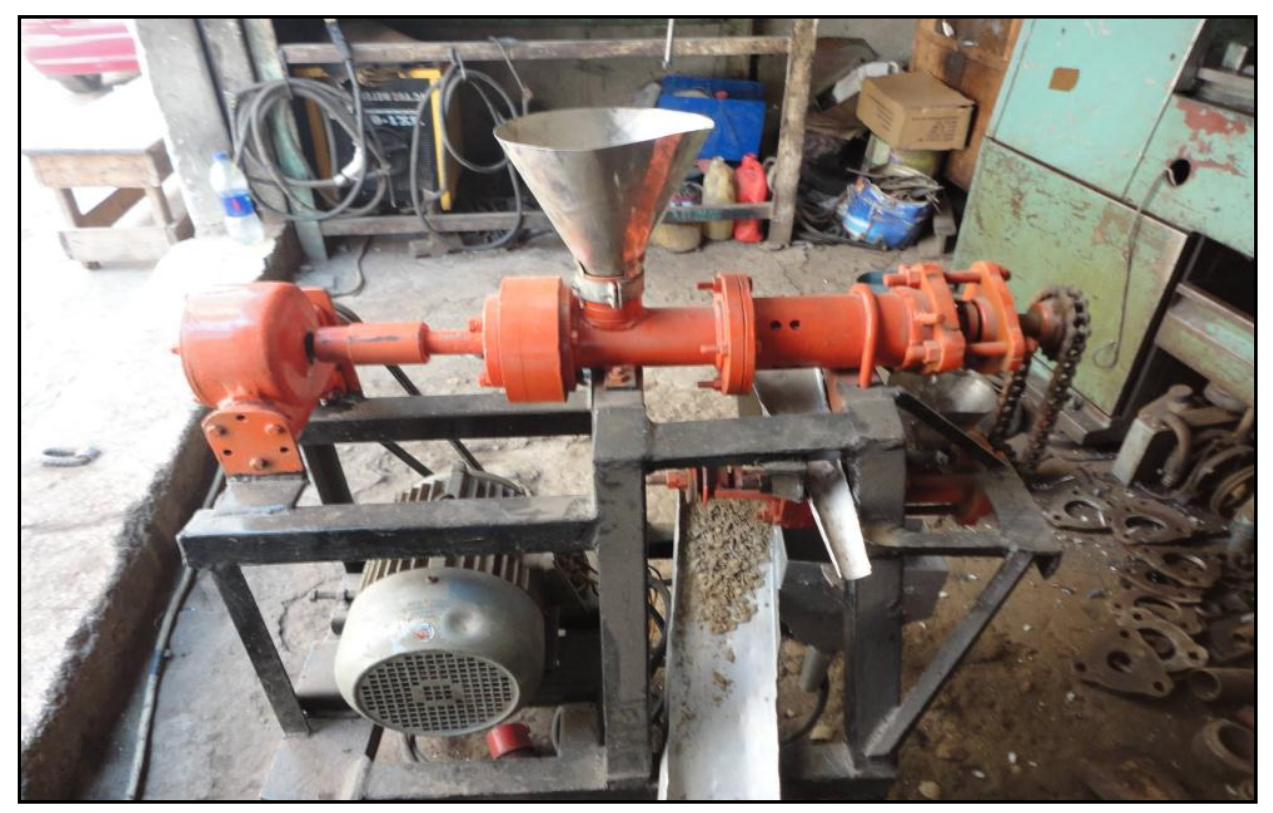

Fig. 3. Photograph of an expelling machine. 


\subsubsection{Hopper:}

Two hoppers were made of stainless steel sheet of $1.5 \mathrm{~mm}$ thickness, with $250 \mathrm{~mm}$ height and $150 \mathrm{~mm}$ average diameter. Lower part tapered to form a cone (lower hole diameter is $40 \mathrm{~mm}$ ). First hopper is used to carry and canalize the wheat germ into the screw press. The second hopper is used to take wheat germ cake after the first compression screw to feed the second screw press. Feeding does not need any energy; gravity is sufficient for feeding.

\subsubsection{Barrel (Cage):}

The first barrel is shown in Fig. (4). It consists of 24 flat steel bars parallel to the worm shaft. The cross section of each bar is slightly trapezoidal, the whole set of the bars are functioned as lining bars which are fixed inside the surface of the cage, where the space between bars created drainage gaps. Also, in this system, lining bars canalize the compressed germ to move forward. They prevent jamming by creating obstacles to the rotating compressed wheat germ, so they are pushed strongly to the forward.

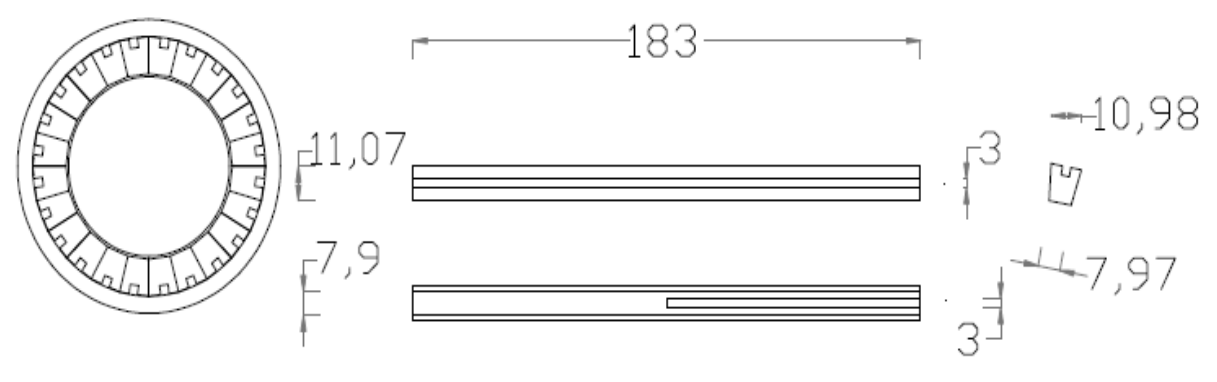

Fig. 4. Flat steel bars.

The second barrel is consisted of 8 triangular barrel rings made of steel with $15 \mathrm{~mm}$ thickness, and have central circular opening, as shown in Fig. (5). the barrel rings are separated by circular spacers, that slide onto the tie bars to form the drained barrel of the press. This arrangement offers greater flexibility to adjust the drainage gaps of the press and forms a very simple assembly that can be easily maintained. The gaps between rings, that are created by PROSBAN material (25mm thickness), allow oil to drain. 


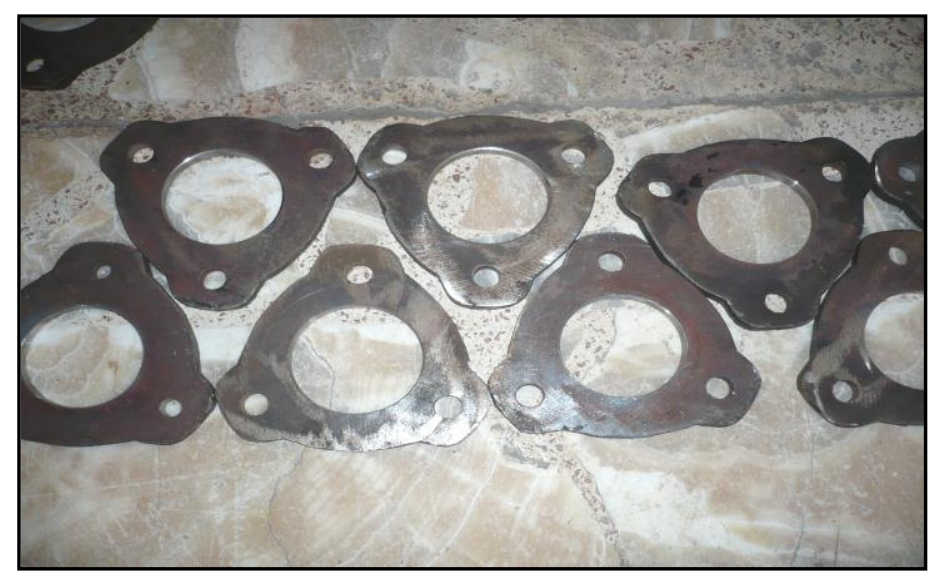

Fig. 5. Photograph of barrel rings with circular spacers

\subsubsection{Screw Shaft:}

\section{A. First Screw Shaft:}

The first screw with tapered root diameter $(60 \mathrm{~mm})$ is designed. The pitch is constant $(5.9 \mathrm{~mm})$, where the annular area is decreasing along the length of the screw shaft $(370 \mathrm{~mm})$ and takes its minimum value at the end of the screw. The swept volume by the screw thread in each turn is the multiplication of the annular area and the pitch distance. During this stage, the increase of pressure rate is higher at the end of screw shaft, which is depended on the taper angle $\left(1.4^{\circ}\right)$ of the shaft. The wheat germs are compressed in two ways. The first way of compression occurs by the continuous feeding of the germs into the system. Newly fed wheat germs compress the germs which are already present in the system. Other way of compression takes place between the inside surface of the barrel and the outer surface of the screw shaft. As the depth of the thread decreases continuously, the distance between these two surfaces decreases. Then, forwardly pushed wheat germs are applied compression between these two surfaces. For these reasons, this type of screw shaft configuration is evaluated as the most appropriate one for this study (Sari, 2006).

A small clearance is found between the barrel and the screw shaft $(1 \mathrm{~mm})$. This small clearance is necessary for avoiding escaping the wheat germs between the outside diameter of the screw shaft and the inside surface of the 
barrel. In such a case, friction force between the screw shaft and barrel increases, and required torque becomes higher.

Screw shaft is a tapered shaft. The outside diameter $(60 \mathrm{~mm})$ is constant whereas the root diameter is inclined through the screw. Thread depth disappears at the end of the screw.

\section{B. Second Screw Shaft:}

The wheat germ cake, which is produced from the first stage press, will be fed into the second stage of the compression screw press. The power is transmitted from the first screw shaft to the second shaft by means of two sprockets, and chain. The second shaft is, also, a tapered shaft and the outside diameter $(50 \mathrm{~mm})$ is constant whereas the root diameter is inclined through the screw. The pitch, also, is constant $(4.9 \mathrm{~mm})$, the length of the screw $(235 \mathrm{~mm})$ and takes its minimum value at the end of the screw, and the taper angle is $1.2^{\circ}$.

The wheat germ is continuously fed through the feeder, the material in the primary section (first screw) moves forward and drop into secondary section (second screw) through the second hoper. In second stage, the compression is more effective since the clearance between the barrel and screw is reduced considerably with the help of the end cone clearance. To accomplish that, the end part of the worm is of conical form. The backward movement of the worm (i.e. movement towards the feed hopper) increases the clearance and thereby reduces the pressure on wheat germ present inside while its forward movement does it otherwise.

\subsubsection{Power transmission:}

The power is transmitted by means of a set of pulleys; sprockets; V-belt; chain and speed reducer (gear box).

The power utilized to drive the expeller is an electric motor (1440 rpm; 4 $\mathrm{kW}$ ), and transmitted by means of pulley and belt, the pulley assembled on the drive shaft of the motor attached with pulley assembled on a gearbox shaft (1:24) by $\mathrm{V}$ belt $(17 \mathrm{~mm})$ to produce $25,35,45,55$, and 65 rpm. Meanwhile the power transmitted from the first screw shaft to the second shaft by means of two sprockets, and chain. 


\subsection{Wheat germ:}

Fresh wheat germ, which was used for all experiments, was taken directly after the milling process from Ibn Al-Khattab Factory in El-Sadat city, and then stored in polyethylene bags at a temperature of $-5^{\circ} \mathrm{C}$.

\section{TEST PROCEDURE}

Many parameters and factors were affecting on the performance, productivity and efficiency of oil extraction processes of wheat germ oil. Some of these parameters and factors are related to the wheat germ (moisture content), some others are related to the expeller machine (screw speed and outlet clearance). Before each experiment:

1. The clearance between conic and choke was adjusted to the required level.

2. The screw speed was adjusted to required level by a means of pulleys

3. The expeller was operated up to the stable condition and the wheat germ sample was poured inside the hoper.

4. As the liquid phase separated from the solid, the resulted wheat germ cake of each sample was taken for determination of remaining oil percentage.

\subsection{Measuring of barrel temperature:}

Each experiment was replicated five times. During the process of oil expression, barrel temperature was measured using an Infrared thermometer with LASAR pointer (resolution $\pm 0.1^{\circ} \mathrm{C}$; Model $42525 \mathrm{~A}$, USA) after $15 \mathrm{~min}$ from starting process of oil expression.

\subsection{Determination of remaining oil percentage:}

The remaining percentage of oil of wheat germ cake was determined by using Soxhlet apparatus technique and redistilled n-hexane according to the method of (AOCS, 1996). Percentage of remaining oil was calculated using the following equation:

$$
\text { Remaining oil, } \%=\left(W_{r} / W_{t}\right) \times 100
$$

Where: $\mathrm{W}_{\mathrm{r}}=$ Weight of the remaining oil, $\mathrm{g}$;

$\mathrm{W}_{\mathrm{t}}=$ Weight of wheat germ sample, $\mathrm{g}$.

\subsection{Determination of oil recovery $(\%)$ :}

Oil recovery $(\mathrm{OR})$ was defined as the ratio of oil weight in the product oil to original weight in the wheat germ that was pressed (Beerens, 2007). It is computed as following: 


$$
O R=\left(1-\frac{W_{C} O_{C}}{W_{m} O_{m}}\right) \times 100 \%
$$

Where: $\mathrm{W}_{\mathrm{C}}=$ Mass of cake, $\mathrm{kg}$,

$\mathrm{O}_{\mathrm{C}}=$ Oil content of cake, $\mathrm{kg}$;

$\mathrm{W}_{\mathrm{m}}=$ Mass of sample, $\mathrm{kg}$, and

$\mathrm{O}_{\mathrm{m}}=$ Initial oil content of sample, $\mathrm{kg}$.

\subsection{Specific Energy Consumption (SEC):}

The power requirement was calculated by using the clamp meter to measure the line current strength and the potential difference value. The total electric power requirement under expeller working load was calculated according to (Chancellor, 1981) and (Ibrahim, 1982) by the following equations:

$$
\mathbf{P}=(\mathbf{I} \times \mathbf{V} \times \cos \theta) / \mathbf{1 0 0 0}
$$

Useful electric power $\left(\mathrm{P}_{c}\right)$ was calculated as the following:

$$
\mathbf{P}_{\mathbf{c}}=\mathbf{P}-\mathbf{P}_{\mathbf{n l}}
$$

Where: $\mathrm{P}=$ The power requirement to extraction oil process, $\mathrm{kW}$.

$\mathrm{I}=$ Line current strength, Amperes.

$\mathrm{V}=$ Potential difference, Voltage.

$\operatorname{Cos} \theta=$ Power factor, equal 0.85 .

$\mathrm{P}_{\mathrm{c}}=$ Useful electric power requirement during machine load, $\mathrm{kW}$.

$\mathrm{P}_{\mathrm{nl}}=$ Power requirement at no load, $\mathrm{kW}$.

The specific energy consumption (SEC) per $\mathrm{kg}$ wheat germ processed in $\mathrm{kWh} \mathrm{kg}^{-1}$ was calculated as ratio of total energy (Et) in $\mathrm{kWh}$ to sample size (S) in kg:

SEC $=\mathbf{E t} / \mathrm{S}$

Where: $\mathbf{E t}=\mathbf{P} \cdot \mathbf{t}$

$\mathrm{P}=$ The power requirement to extraction oil process, $\mathrm{kW}$.

$\mathrm{t}=$ Time in hour.

\section{RESULT AND DISCUSSION}

\subsection{Machine capacity $\left(\mathrm{kg}_{\text {feed }} / \mathrm{h}\right)$ :}

As shown in Fig. (6), the machine capacity increased with the increase of screw speed, and decreased with the decrease of the outlet clearance, it 
was $15.18,18,21.6,25.2$, and $27.6 \mathrm{kgh}^{-1}$ when outlet clearance was $0.5 \mathrm{~mm}$ while at $2 \mathrm{~mm}$ clearance, it was $22.2,26.4,30,34.2$, and 37.8 $\mathrm{kgh}^{-1}$ at $25,35,45,55$, and $65 \mathrm{rpm}$ respectively.

\subsection{Oil recovery $(\%)$ :}

Fig. (7) Shows that, the oil recovery increased with the decrease of the outlet clearance, while it was decreased with the increase of screw speed. The maximum oil recovery was obtained at $0.5 \mathrm{~mm}$ outlet clearance and $25 \mathrm{rpm}$ of screw speed when a total of $50.2 \%$ of the available oil in the sample was recovered. At $0.5 \mathrm{~mm}$ outlet clearance the oil recovery decreased from 50.2 to $41.62 \%$ with increasing screw speed from 25 to $65 \mathrm{rpm}$, while at $1 \mathrm{~mm}$ outlet clearance, it was decreased from 48.1 to $38.3 \%$, and from 46.2 to $36.4 \%$ at $1.5 \mathrm{~mm}$ outlet clearance. Meanwhile at $2 \mathrm{~mm}$ outlet clearance it was decreased from 44.4 to $34.1 \%$, with increasing screw speed from 25 to $65 \mathrm{rpm}$ respectively.

\subsection{Residual oil (\%):}

Fig. (8) Indicates that, the residual oil increased with the increase of the outlet clearance, while it was decreased with the decrease of screw speed. The minimum residual oil $(49.8 \%)$ was obtained at $0.5 \mathrm{~mm}$ outlet clearance and $25 \mathrm{rpm}$ of screw speed. At $0.5 \mathrm{~mm}$ outlet clearance the residual oil decreased from 58.38 to $49.8 \%$ with decreasing screw speed from 65 to $25 \mathrm{rpm}$, while at $1 \mathrm{~mm}$ outlet clearance it was decreased from 61.7 to $51.9 \%$, and from 63.6 to $53.8 \%$ at $1.5 \mathrm{~mm}$ outlet clearance. Meanwhile at $2 \mathrm{~mm}$ outlet clearance it was decreased from 65.9 to 55.6 $\%$, with decreasing screw speed from 65 to $25 \mathrm{rpm}$, respectively.

\subsection{Specific Energy Consumption (SEC) ( $\mathrm{kWh} / \mathrm{kg}$ feed):}

Results illustrated in Fig. (9), show that SEC increased with the decrease of the outlet clearance, while it had a little decrease with increasing the screw speed from 25 to $65 \mathrm{rpm}$ at the same outlet clearance, SEC decreased from 0.0426 to $0.0304 \mathrm{kWhkg}^{-1}$ feed with the increase of the screw speed from 25 to $65 \mathrm{rpm}$, respectively. 

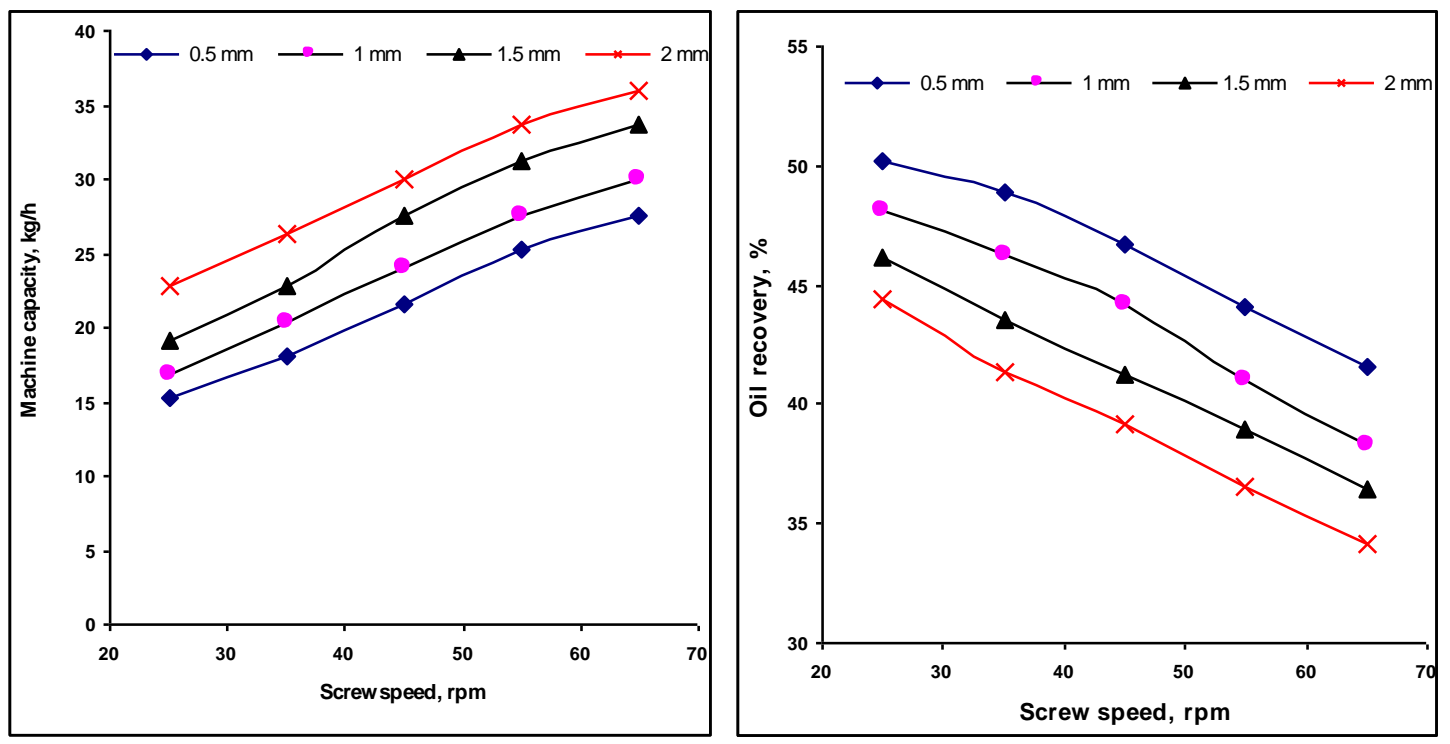

Fig.6: Effect of screw speed and outlet Fig.7: Effect of screw speed and outlet clearance on machine capacity $\mathrm{Kgh}^{-1}$. clearance on oil recovery, $\%$.
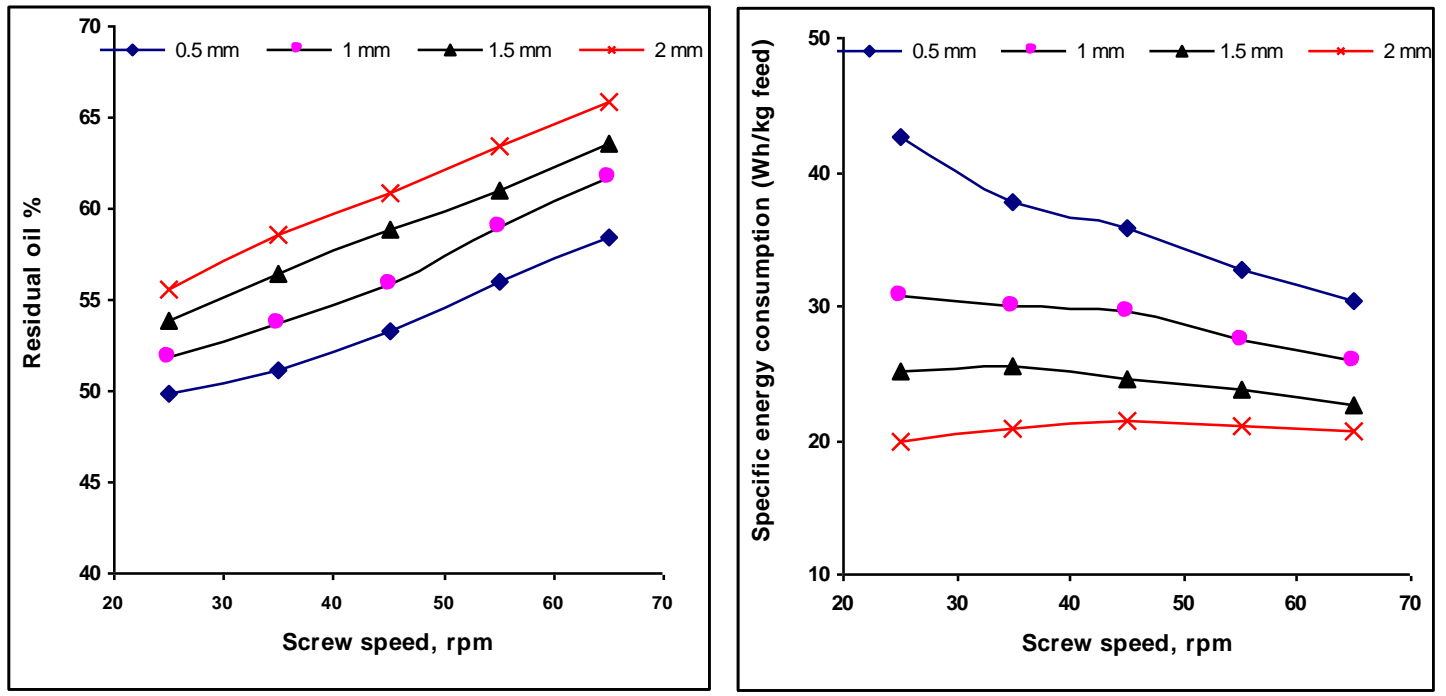

Fig.8: Effect of screw speed and outlet clearance on residual oil, $\%$, in wheat germ cake.

Fig.9: Effect of screw speed and outlet clearance on specific energy consumption $\left(\mathrm{kWhkg}^{-1}\right.$ feed $)$ 


\subsection{Barrel temperature, ${ }^{\circ} \mathrm{C}$ :}

The developed expeller operated smoothly throughout the experiments without any observed choking or jamming. This may also be reflected in the recorded range of maximum barrel temperatures $\left(51.1\right.$ to $\left.65.5^{\circ} \mathrm{C}\right)$ during the operation of the press. As shown in Fig. (10), the barrel temperature decreased with the increase of the outlet clearance, while it was increased with the increase of screw speed.

The designed expeller exhibited additional benefits as follows:

- A marginally reduced applied pressure which did not adversely affect the oil recovery rate, but helped in eliminating the most prevalent problem namely choking/ jamming found in oil expellers. This, in turn, considerably reduced energy losses, man-hours of operation the wear and tear of the barrel components when compared with operation of a conventional screw press under similar conditions of operation.

- Elimination of choking/jamming reduced frictional heat so that the screw and the barrel temperature remained lower than the $70^{\circ} \mathrm{C}$, despite the longer barrel as well as duration of operations. This is important because barrel temperatures above $70^{\circ} \mathrm{C}$ have been reported to adversely affect the cake and oil quality (Ohlson, 1976; and Megahed, 2011).

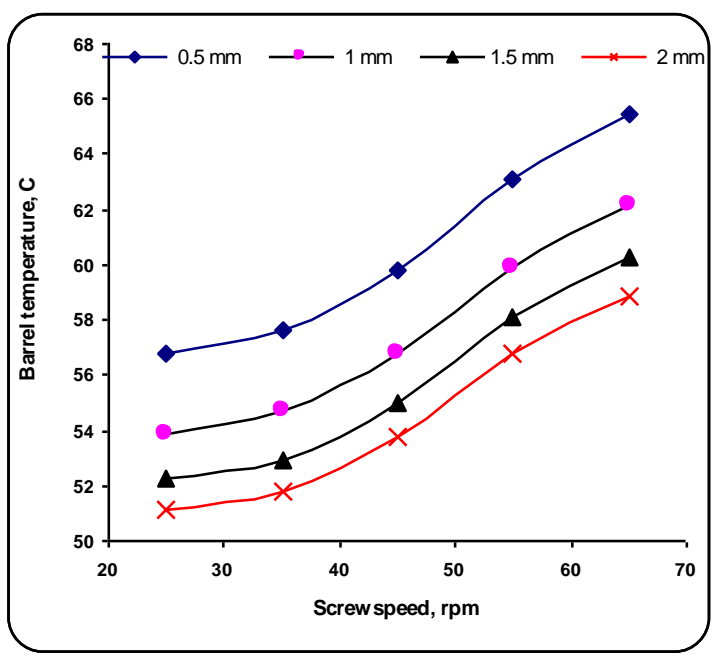

Fig.10: Effect of outlet clearance and screw speed on Barrel temperature, ${ }^{\circ} \mathrm{C}$. 


\section{CONCLUSIONS AND RECOMMENDATION}

An expeller machine was designed and fabricated. The unit was tested and found capable of expressing oil from small quantities of the oil-seed (wheat germ). The oil obtained was found to be of high quality as its characteristics were comparable to literature values for wheat germ oil, This may also be reflected in the recorded range of maximum barrel temperatures $\left(51.1\right.$ to $\left.65.5^{\circ} \mathrm{C}\right)$ during the operation of the press.

Results showed that the expeller could be pressed wheat germ on two stages to give a better performance at the speed of $25 \mathrm{rpm}$, when outlet clearance of cake was at $0.5 \mathrm{~mm}$.

\section{REFERNCES}

A.O.C.S. 1996. The Official and Tentative Methods of the American Oil Chemist's Society, 3rd Ed. American Oil Chemist's Society, 508 South Sixth Street, Champaign, Illinois.

Barnes, P. J. 1982. Lipid composition of wheat germ and wheat germ oil. Fette Seifen Anstrichmittel, 84, p. 256.

Beerens, P., 2007. Screw-pressing of Jatropha seeds for fuelling purposes in less developed countries. M.Sc. Thesis, Department of Sustainable Energy Technology, Eindhoven University of Technology, Eindhoven, p. 87.

Bockisch, M. 1998. Fats and oils Handbook. Champaign, Illinois: AOCS press.

Carr, R. 1997. Oilseed processing. In Technology and solvents for extracting oilseeds and nonpetroleum oils, eds. P. Wan and P. Wakelyn, 101-120. Champaign, Illinois: AOCS press.

Chancellor, W. J. 1981. Substituting information for energy in agricultural. Trans. ASAE, Paper No. 0001- 2351.

Coultate, T. 1989. Food, the chemistry of its components; The Royal Society of Chemistry: London, UK, Chapter 4.

Dunford, N. T. 2005. Germ oils from different sources. In: Bailey's Industrial Oil and Fat Products, $6^{\text {th }}$ Ed. Editor: F. Shahidi. John Wiley and Sons, N.J. Vol. 3, "Edible Oil and Fat Products: Specialty Oils and Oil Products", Ch. 8, pp. 195-231. 
FAO, 2010. Production year book, for 2009. Food and Agriculture Organization of the United National. Rom. http://www.fao.org/corp/statistics/en/

Ibrahim, M. K. E. 1982. Wet Milling Wheat Grain. Master thesis of science. Fac. of Agric. Mansoura Univ., 64-65.

Megahed, M. G. 2011. Study on stability of wheat germ oil and lipase activity of wheat germ during periodical storage. Agric. Biol. J. N. Am., (1): 163-168.

Ohlson, I. S. R. 1976. Processing effects on oil quality. Journal of the American Oil Chemists' Society, 53, 299-301.

Peterson, C. L.; D. L. Auld and J. C. Thompson. 1983. Experiments with vegetable oil expression. Transaction of ASAE. 26:12981302.

Sari, P. 2006. Preliminary Design and Construction of a Prototype Canola Seed Oil Extraction Machine. Master thesis of science. Department of Mechanical Engineering, Middle East Technical Univ., Ankara, Turkey. 109.

Shuler, P. 1990. Natural antioxidants exploited commercially, in Food Antioxidants, Hudson, B.J.F, Elsevier Applied Science, England, Chap.4.

Singh, J.; and P. C. Bargalo. 2000. Development of a small capacity double stage compression screw press for oil extraction. Journal of Food Engineering, 43: 75-82.

Singh, K. K.; D. Wiesenborn; N. Kangas; and K. Tostenson. 2002. characterization of preparation parameters for improved screw pressing of crambe seed. Transaction of ASAE. 45:1029-1035.

Wang, T. and L. A. Johnson. 2001. Refining high-free fatty acid wheat germ oil. Journal of the American Oil Chemists' Society, 78 (1): 71-76.

Woerfel, J. B. 1995. Extraction. In: Erickson DR, editor. Practical handbook of soybean processing and utilization. American Oil Chemists' Society, Champaign, IL: AOCS Press. p 65-92. 


\section{الملخص العربي}

\section{تقييم آلة لاستخلاص الزيت من جنين القمح القيح}

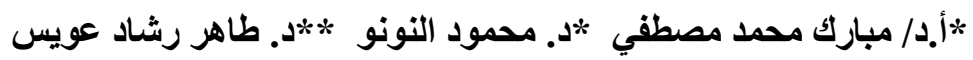

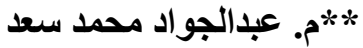

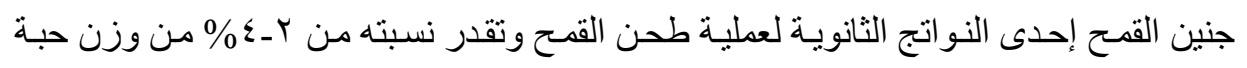

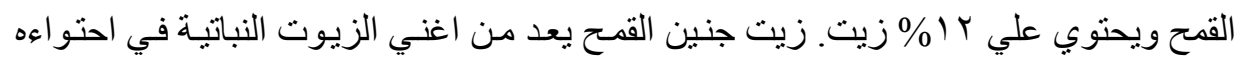

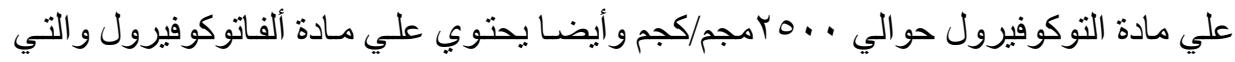

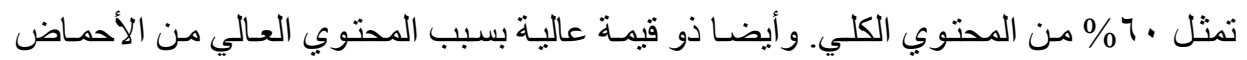

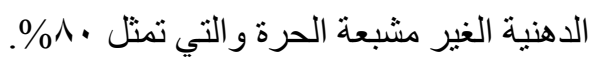

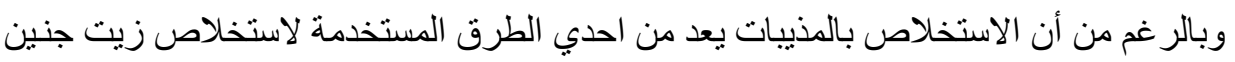

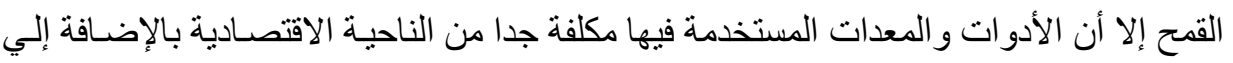

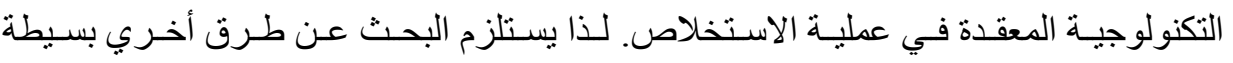
لاستخلاص الزيت من جنين القمح. لذلك تم تصنيع وتطوير وحدة لاستخلاص زيت جنين القـح

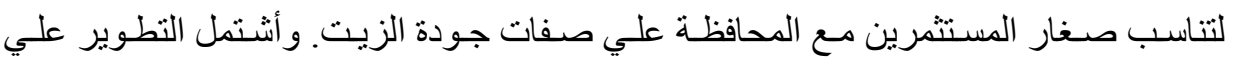
تصميم ماكينة صغيرة لاستخلاص الزيت تعمل بنظام الضغط المستمر علي مرحلتين كبس مـع استخر اج الكسب علي صورة رقائق لاستخدامها في التغذيـة الحيو انيـة و الداجنـة. وتـم تقييم أداء

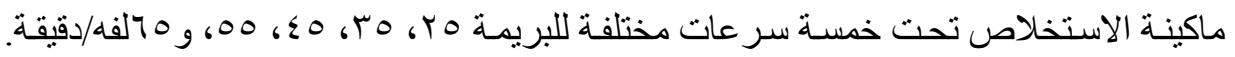

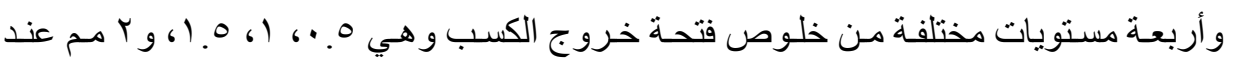

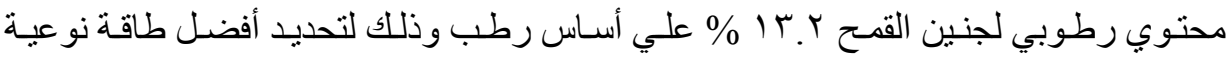
مستهلكة (ك وات ساعة/كجم تغذية)، السعة الميكانيكية(كجم/ساعة)، كفاءة الاستخلاصب(\%)؛ نسبة الزيت المتبقي بالكسب(\%). وتم أيضا قياس درجة حرارة أجزاء الاستخلاص أثناء عملية

الفصل.

$$
\text { وقد توصلت الار اسة إلى النتائج الآتية: }
$$

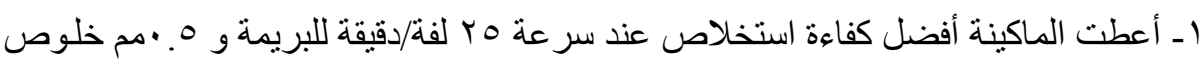

$$
\text { فتحة خروج الكسب. }
$$

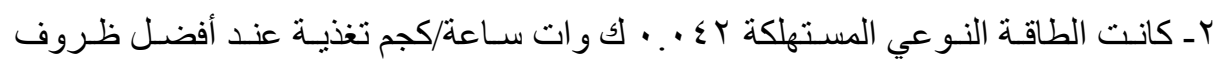

$$
\text { استخلاص للزيت. }
$$

rـ أقصي درجة حرارة تعرض لها جنين القمح عند الاستخلاص باستخدام هذه الماكينـة 0.0

$$
\text { م م وهي مناسبة للمحافظة علي جودة الزيت و الكسب. }
$$

* قسم الهندسة الزراعية ـ كلية الزراعة ـ جامعة عين شمس - القاهرة. **معهد بحوث الهندسة الزراعية ـ مركز البحوث الزية الزراعية ـ الدقي- جيزة. 